\title{
Reproductive System Structure, Development and Function in Cephalopods with a New General Scale for Maturity Stages
}

\author{
A. I. Arkhipkin \\ Atlantic Research Institute of Marine Fisheries and Oceanography (AtlantNIRO) \\ 5 Dmitry Donskoy Street, Kaliningrad, 236000, USSR
}

\begin{abstract}
The main types of reproductive system structure, development and functions in cephalopods are described from personal observations and use of the literature. There is one type in males and three in females which are order specific. These have provided a basis for examining possible evolutionary trends in reproductive system development and in reproductive strategies within coleoid cephalopods and for developing a general scale for maturity staging for males and females. Development of the cephalopod reproductive system consists of two main phases. The first includes sexual cell differentiation, growth and maturation (i.e. juvenile phase and physiological maturation). The second begins after maturation of sexual cells. It includes their transport and accumulation in different parts of the reproductive system and their conversion into spermatophores in males and eggs with protective coverings in females (i.e. physiological maturity, functional maturation and maturity). It was found that species with different life styles within each order have similar reproductive systems. This may be attributable to the relative youth in an evolutionary sense of the main groups of living cephalopods. A general scale of seven maturity stages for cephalopods was developed. Distinct characteristics of each stage are described and supplemented with a generalized drawing of gonad structure. In the first phase of reproductive system development, maturity stages are distinguished by the degree of development of the gonad and accessory glands. In the second phase maturity stages are distinguished by the fate of the mature sexual cells, particularly by their transport and location in different parts of the reproductive system up to the time of spawning.
\end{abstract}

\section{Introduction}

A structure of the reproductive system in cephalopod males and females usually has been included in descriptions of new species. There are several thorough reviews on reproductive system structure for the main cephalopod orders (Arnold and Williams-Arnold, 1977; Wells and Wells, 1977; Nesis, 1982). The development and function of the reproductive system have been studied to a much lesser extent. Detailed descriptions are available only for a dozen of the most important commercial species, particularly the Ommastrephidae and Loliginidae such as Illex illecebrosus (Durward et al., 1979; Burukovsky et al., MS 1984) and Loligo opalescens (Fields, 1965; Grieb and Beeman, 1978).

Evolution of the reproductive system in cephalopods as well as cephalopod reproductive strategies have received little attention. Reproductive strategies of cephalopods were studied by von Boletzky (1981, 1986) but even in the most recent edition of "Paleontology and Neonatology of Cephalopods" (The Molluscs, 1988) there is no consideration of the evolution of the cephalopod reproductive system.
Various scales have been developed for cephalopod maturity stage determination (Juanico, 1983). Traditionally authors developed and used their own scales. Criteria for dividing the process of sexual development into maturity scale usually involve complex sexual characters. Common terminology for cephalopod maturity stages include juvenile, immature, maturing, mature and spent. However, authors often apply different meaning to these (Juanico, 1983) and such broadly used terms create difficulties when standard criteria are required for maturity staging.

Maturity scales with well defined visual, meristic and weight characteristics are available, for instance, for Illex illecebrosus (Burukovsky et al., MS 1984; Nigmatullin et al., MS 1984) and Sthenoteuthis pteropus (Burukovsky et al., 1977; Zuev et al., 1985). The authors point out that patterns of gonad and accessory gland development are species-specific and it is necessary to develop a maturity scale for each. This approach, however, makes comparison of the development of reproductive systems in different species very difficult. Therefore it seems worthwhile to develop a general maturity scale for cephalopods which could be used to describe and distinguish all the stages of sexual devel- 
opment in males and females of different species. Such a scale should describe the same processes of reproductive system development by the same maturity stages and should be convenient for the study and comparison of reproductive systems as well as reproductive strategies.

The purpose of this paper is to describe the main types of reproductive system structure, development and function in all living cephalopod orders of the Subtype Coleoidea. This has provided a basis for examining possible evolutionary trends in reproductive system development and in reproductive strategies within coleoid cephalopods and for developing a general scale for maturity staging for males and females.

\section{Materials and Methods}

Details of the structure of the reproductive system of the Ommastrephidae squids IIlex illecebrosus (juveniles mainly), Dosidicus gigas and Sthenoteuthis pteropus (from juveniles to adult), Illex argentinus (adults mainly) were obtained from biological dissections of several thousand specimens. Details for other species were obtained from the literature. Additionally, V. V. Laptikhovsky (AtlantNIRO, Kaliningrad, pers. comm.) kindly provided results of his studies of oocyte state in ovaries of 50 individuals of 14 species as follows: Octopus vulgaris ( 3 specimens), Argonauta argo (1 specimen), Tremoctopus violaceus (4 specimens), Sepia bertheloti (3 specimens), Sepiella ornata (1 specimen), Abraliopsis atlantica (8 specimens), Pterigioteuthis gemmata (7 specimens), Onychoteuthis banksi (2 specimens), Illex argentinus (13 specimens), Todaropsis eblanae (1 specimen), Ornithoteuthis antillarum (1 specimen), Gonatus fabricii (3 specimens), Octopoteuthis sicula (1 specimen), Histioteuthis reversa (2 specimens). He determined dimensions, presence or absence of nucleoli in nuclei, and in most cases, degree of follicle formation.

A five-level scale of maturity stages for squids used at the AtlantNIRO laboratory (Burukovsky et al., 1977) was the basis for developing a general scale for cephalopod maturity states. Characteristics of each stage were described using the terminology of Nigmatullin and Sabirov (1987) and Burukovsky et al. (1977). Possible evolution of living cephalopods was considered according to Nesis (1985), characters of $r$ - and k-type reproductive strategies were determined according to Boletzky (1981).

\section{Structure of the Reproductive System}

Cephalopods are short-cyclic and monocyclic (with the exception of Nautilus) animals with a structu- rally complex reproductive system. In general, the system in males and females consists of a gonad (testis and ovary) located in the coelom in the posterior part of the body, one or two separate gonoducts and a complex of accessory glands which produce different secretion for enhancement and protection of ripe sexual cells. The main types of reproductive system structure in cephalopods are illustrated in Fig. 1.

Females. The reproductive system is simplest in the octopus. The gonad is oval with two tubular oviducts. The oviducal glands are set on the oviducts like a ring and are attached to the sexual coelom (Wells and Wells, 1977).

The reproductive system is more complex in cuttlefish than in the octopus. The ovary is semi-spherical with two straight oviducts. Accessory glands are of three kinds. Oviducal glands, in contrast to those of the octopus, are found in the distal end of oviduct positioned in a way such that occytes emerging from the oviducts pass their cavities. There are also nidamental glands which are usually oval and accessory nidamental glands whose function is unknown (Nesis, 1982).

A diversity of reproductive system structure is found in squid. As a rule, the gonad is conical. Only one oviduct is developed in some (subfamily Pyroteuthinae and suborder Myopsida) and both are developed in others (the remainder of the suborder Oegopsida). Oviducts are strongly curved tubes with a small funnelshaped entrance. Three kinds of accessory glands are present in suborder Myopsida (oviducal, nidamental and accessory), while in the suborder Oegopsida only oviducal and nidamental glands are found. In the subfamily Enoploteuthinae, oviducal glands are well developed but nidamental glands are present.

Males. The structure of the reproductive system is more uniform than in females among the orders of coeloid cephalopods. The single testis is rounded (in octopus) or conical (in cuttlefish and squid). The spermduct is usually unpaired and curved with its proximal end enlarged to form an ampulla. The spermduct extends into a spermatophoric gland where the spermatophore is formed. The spermatophore is characteristic of the male cephalopod. The spermatophoric gland is connected by the spermatophoric duct to the Needham sac (spermatophore depository). The distal part of the Needham sac is muscular and functions as a penis. In some species the spermatophoric organs are paired, e.g. in Histioteuthis hoylei, Selenoteuthis scintillans and Oregonioteuthis springeri (Nesis, 1982). In general, the male reproductive system is more complicated than in females, especially because of the greater number of accessory glands involved in spermatophore formation. 


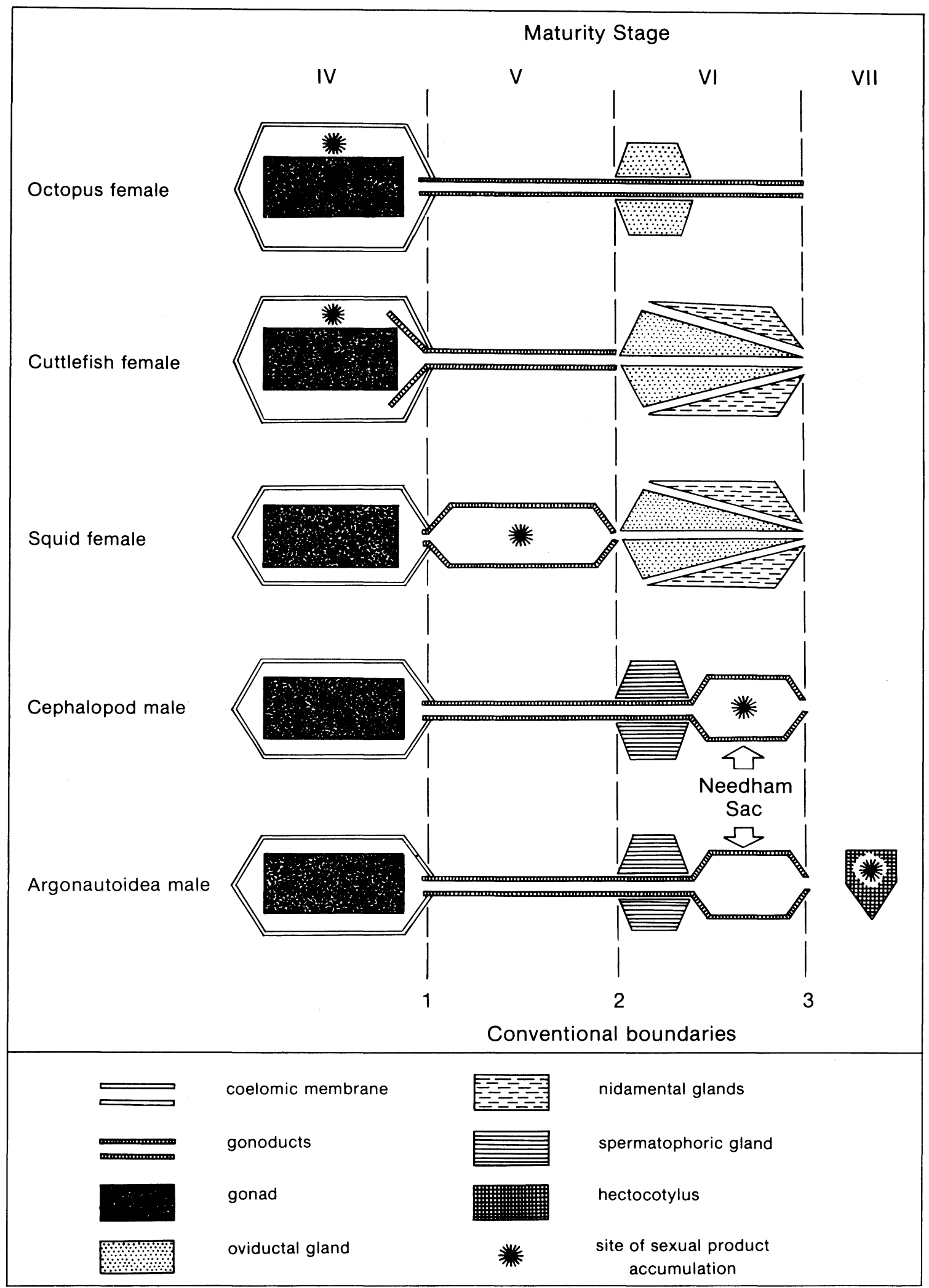

Fig. 1. General schemes of reproductive system structure in cephalopods. 


\section{Development and Function of the Reproductive System}

The development of the reproductive system takes place in several phases as follows:

1. Juvenile - the gonad forms, the germinal epithelium differentiates and accessory glands form.

2. Physiological maturation - formation of mature sexual cells takes place in the gonad, i.e. oogenesis or spermatogenesis. Accessory glands grow and their parts form.

3. Physiological maturity - mature sexual cells are expelled from the gonad to the sexual coelom.

4. Functional maturation - mature sexual cells ripen for spawning. In females, this involves formation of additional oocyte coverings and the process of transferring oocytes into the organs from which spawning will take place. In males this involves formation of spermatophores which provide for the transfer of spermatozoa to the female without loss.

5. Functional maturity - the reproductive system is completely ready for spawning.

In the simplest case, which is spawning into the water without preliminary treatment by accessory gland secretions (Patella, primitive mussels), the organism is ready for spawning at physiological maturity. In higher forms (higher Gastropoda, Cephalopoda) the mature sexual cells undergo a number of processes (formation of additional coverings and formation of spermatophores) before spawning occurs.

In monocyclic animals, which represents the majority of living cephalopods (Nesis, 1985), the reproductive system undergoes the first three phases only once, and the fourth and fifth phases either once for one-time-only spawners or repeatedly for species that spawn more than once.

The following description of the main processes which take place during reproductive system development in different groups of cephalopods is aimed at providing a basis for further subdivision into stages of maturity as well as a consideration of the evolution of reproductive strategies. The processes which take place during maturation of the sexual cells (i.e. juvenile phase and physiological maturation) are treated separately from the processes of further development and treatment of these cells (i.e. physiological maturity to functional maturity).

\section{Juvenile phase and physiological maturation}

Initially the embryonic gonad in octopus is paired but it becomes fused in young animals (Wells and
Wells, 1977). Gonads are unpaired in cuttlefish and squid from the start (LeMaire 1972; Fioroni, 1978).

Females. Oogenesis is similar in different cephalopod groups (Arnold and Williams-Arnold, 1977). An oocyte develops in successive stages from a simple to a complex follicle followed by vitellogenesis which ends in follicle expulsion and ovulation. Despite the similarity, the stages are evidently not identical. The most important difference is the time of nucleoli decomposition and R-RNA penetration in oocyte cytoplasm observed in different species with different follicle condition. In Lolliguncula brevis, Alloteuthis subulata, Loligo opalescens, Octopus tehuelcus and Dosidicus gigas this takes place during intercalation (Cowden, 1968; Bottke, 1974; Knipe and Beeman, 1978; Pujals, 1986; Michel et al., 1986). Disappearance of nucleoli in IIlex argentinus precedes the formation of folds in the follicular epithelium (Shuldt, 1979). Examination of oocytes in different developmental stages by Laptikhovsky (AtlantNIRO, Kaliningrad, USSR, pers. comm.) suggests different episodes of nucleoli appearance and disappearance. Nucleoli are not distinguishable before simple follicle formation in Octopoteuthis sicula, Sepia bertheloti and Abraliopsis atlantica. In Argonauta argo and Pterigioteuthis gemmata, at the stage when the simple follicle nucleoli start decomposing, they acquire a characteristic blot shape as observed in IIlex argentinus (Shuldt, 1979). In Octopus vulgaris, nucleoli remain unaltered until complex follicle formation and probably, disappear just before vitellogenesis begins.

Males. Spermatogenesis also varies in different cephalopods. In Loligo opalescens primary spermatocytes have not been observed in maturing nor mature individuals (Grieb and Beeman, 1978). In mature IIlex argentinus not only primary spermatocytes but gonial cells also are found in the testis (Shuldt, 1979). In octopus, protoplasmic growth of spermatozoa in the gonad as well as gonoduct development take place independent of optic gland activity (Buckley, 1976). In castrated juvenile octopus, spermducts and spermatophoric glands develop normally (Taki, 1945; Wells and Wells, 1977). This suggests that during the juvenile phase and through physiological maturation, the gonad and accessory glands function asynchronously.

At physiological maturity these two organs function synchronously. Preliminary activity in accessory glands takes place shortly before the mature sexual cells are expelled, i.e. formation of preliminary spermatophores takes place in the spermatophoric gland (Laptikhovsky and Nigmatullin, 1987).

\section{Physiological maturity, functional maturation and maturity}

Females. The simplest type of reproductive system is found in octopus. In primitive octopus of the sub- 
order Cirrata, ripe oocytes do not accumulate in the coelom. Rather, immediately after ovulation they are released one by one into the oviducts where they are covered with a thick shell formed by the secretion of the oviductal glands (Aldred et al., 1983; Boletzky,.1979).

Short-term accumulation of oocytes in the coelom, and usually a single spawning, occur in octopus of the suborder Incirrata. Octopus zonatus, in which repeated spawning has been observed (Rodaniche, 1984), is an exception.

In cuttlefish, mature oocytes accumulate mostly in the coelom but partially in the proximal ends of the oviducts which form a wide, concaved funnel.

Mature oocytes accumulate in the oviducts of squid in preparation for spawning. Spawning occurs only once in Todarodes pacificus (Hamabe, 1962) but the process of oocyte accumulation in the oviducts is repeated in multiple spawners such as Thysanoteuthis rhombus (Arkhipkin et al., 1983), Berryteuthis magister (Reznik, 1983) and Stenoteuthis oualaniensis (Harman et al., 1989).

It is important to clarify the homology of accessory glands in cephalopods. Gastropod accessory glands are different in origin, and form egg coverings at spawning. A mucous secretion is formed by pallial, pedal and hypobranchial glands in different species of this class. In mollusks which lay their eggs in rigid capsules, capsule glands and albumin glands are present in a complex of pallial glands. These differ in their origin and function (Chukchin, 1984).

Oviductal glands in octopus secrete an adhesive cement, while those of cuttlefish and squid secrete a light mucous which forms the third egg covering. Nidamental glands in squid and cuttlefish also differ both in form and secretion. In cuttlefish the secretion is a fourth covering forming thick egg capsules, but in squid the nidamental glands secrete a mucous mass at spawning.

Octopus and cuttlefish usually lay eggs one by one on the substrate. When several are laid at the same time, a cluster of individual eggs is formed. The eggs are sheltered and protected by the female in octopus but not in cuttlefish.

In squid, with the exception of Enoploteuthinae, (Young and Harman, 1985), eggs form a complex structure. At spawning, eggs are immersed in a mucous secretion of nidamental glands which forms the fourth covering (Hamabe, 1962). The mucous is inedible and provides protection for embryos to develop within the mass. In squid, each spawning tends to be specific in terms of size and number of eggs (Hamabe, 1962; Sanzo, 1929; Sabirov et al., 1987). Thus accumulation of ripe eggs must be synchronized with secreting accessory glands for successful formation of the egg mass at spawning. In squid, oocytes at different stages of development are found within the gonad at the same time. If ripe eggs are accumulated in the coelom, as in some octopus and cuttlefish, all the oocytes in the gonad would be laid at the same time. Possibly, benthopelagic or nektobenthic ancestors of squid spawned this way but there is probably survival advantage for monocyclic animals with a short life span inhabiting various environments in laying portions of their total fecundity periodically. Asynchrony in gonad development and accumulation of portions of mature oocytes in the oviducts rather than in the coelom may be an adaptation by squid that enhances survival of young.

Males. As spermatozoa mature and are released from the testis they pass directly to the spermaduct which is surrounded by a complex of accessory glands. The first glands inactivate the spermatozoa and others cover the sperm mass with different secretions to form the spermatophore (Drew, 1919). Spermatophores usually accumulate in the Needham sac. Each spermatophore is therefore analogous to a single egg laying of a female squid. Usually only a portion of the spermatophores from the Needham sac is transferred to any female.

Males of the most primitive recent cephalopods (octopus of the suborder Cirrata) produce sperm packets rather than spermatophores. In each of these packets spermatozoa are positioned with their tails towards the centre and heads towards the periphery (Aldred et al., 1983). In octopus of the Argonautoidea superfamily (Fig. 1) only one spermatophore is formed in the spermducts. This spermatophore "bursts" in the Needham sac and its contents are transferred to the seminal reservoir on a specialized arm called the hectocotylus. The hectocotylus detaches during copulation and is inserted into the female mantle cavity (Nesis, 1982).

In primitive mussels (Monoplacophora and others) the male sexual system is organized and functions similarly to that of female octopus, i.e. sperm accumulate in sexual coelom and are released into the spermduct at spawning. In primitive prosobranch mollusks (Littorina) the male sexual system functions similarly to that of female squid, i.e. sperm accululate in the enlarged part of the spermduct. In higher prosobranchs (Ptenoglossa), spermatozoa are formed into special structures called spermatozeugmae which are able to move actively (Chukchin, 1984). In some higher gastropods (pulmonate mollusks - Stylommastophora), spermatophore formation takes place in the sexual viae and accumulate in the Needham sac which is similar to what occurs in some cephalopod males.

In higher gastropods, sperm is transferred to the female cloaca by a special copulatory organ (penis), 
which is either a body wall protrusion or a modified tentacle. In cephalopods, the distal part of the Needham sac has slightly muscular walls and forms what is termed a "penis" which serves not for internal fertilization but for sperm transfer. This transfer is either directly to a female (for example, in squid (Onychoteuthis sp.)) with a long penis or in most cases to the hectocotylized part of a ventral arm (in squid (Ommastrephes sp. and others)) with a short penis.

\section{Types of Reproductive Strategy and Evolution}

Differences in reproductive system structure and function (particularly in females) suggest how living cephalopod groups may have evolved to occupy various ecological niches in the ocean.

All living cephalopods appeared in the Early Paleocene which is relatively recent in geological time. Division of Orders took place in the Upper Triassic-Early Jurassic and the main orders developed in the Neocene. Apparently, main types of reproductive system structure were already formed by the Mesozoic era in all three orders and remained order specific in spite of the fact that many species with different life styles evolved within each order in the Neocene (Nesis, 1985).

Cephalopods with similar life styles but belonging to different orders did not evolve similar reproductive systems during a short geological time period. For example, species of living octopus, cuttlefish and squid inhabit oceanic waters pelagically but have different types of reproductive systems. However, other living forms from different orders evolved similar benthopelagic life styles during a long geological time period. For example, nautilus and finned octopus lay eggs one by one on the bottom with a thick skin-like shell protecting the embryo from unfavourable environmental conditions and predators.

Octopus. As octopus of the suborder Incirrata developed the benthic mode of life, their reproductive strategy changed considerably from their ancestors (Fig. 2). In all species of Incirrata, eggs accumulate in the coelom in small (deep-water Benthoctopus, Bentheledone) or large quantities (some of Octopus, Eledone) and are then released in a single spawning. Eggs are attached individually to shelters by means of oviducal gland secretions. Eggs are usually protected by females (Boletzky, 1981). As a rule, females die after eggs hatch. In small-egged species there is indirect development with a pelagic larva while in large-egged species there is direct development to bottom-dwelling juveniles. Since most octopus are large-egged, kselection dominates with $r$-selection appearing only in small-egged species (Boletzky, 1981).

As octopus (especially holopelagic species) developed a pelagic mode of life, the main characteristic of their benthic ancestors, protection of eggs by the females, was retained as they entered the midwater. Females of the family Alloposidae possibly lay eggs at the bottom in spite of their own planktonic mode of life (Nesis, 1982). Females of epipelagic species Tremoctopus violaceus, as well as those of midwater species of Bolitanidae and Amphitretidae families, bear eggs in their arms, similar to bottom dwelling Hapalochlaena maculosa. Argonauta, to protect eggs borne in arms, developed a shell which is not homologous to that of nautilus (Boletzky, 1981). Finally, development of eggs in the oviducts (ovoviviparity) is observed in epipelagic Ocythoe and midwater Vitreledonella. Thus, in all these octopus where eggs are protected up to the moment larvae are hatched and at which time they enter the pelagic layers, $\mathrm{k}$-selection dominates.

Cuttlefish. Reproductive strategies of cuttlefish are different from those of octopus (Fig. 2). They are mainly nektobenthic animals which also accumulate eggs in the coelom similar to octopus, however, before spawning the eggs are covered with oviducal gland secretions and also with a thick capsule secreted by the nidamental glands. Eggs are laid one by one or in clusters in different kinds of shelters or on hard substrates and are usually left unprotected (Choe, 1966). Females of some species cover eggs with ink or "roll" them in sand (Boletzky, 1983). Since eggs of cuttlefish are heavier than water (due to the thick, hard shell) no species of this order has become holopelagic.

Within the order, a transition to the benthic mode of life has occurred in Rossinae, Sepiolinae, Sepiadaridae. Both micronektonic Heteroteuthis (Boletzky, 1978) and planktonic Spirula are "forced" to lay eggs on the bottom and their distribution is restricted to continental shelf waters.

Among sepiids there are both large-egged species with bottom-dwelling juveniles (Sepiidae, Sepiadaridae, Sepiolidae) and small-egged species with pelagic larvae (Idiosepidae, Heteroteuthis). In cuttlefish, as in octopus, $\mathrm{k}$-selection dominates with $\mathrm{r}$-selection only in small-egged species.

Squid. Squid exhibit a third kind of reproductive strategy (Fig. 2). Their nidamental glands secrete a neutrally buoyant mucous mass in which eggs are suspended (O'Dor and Balch, 1985). This has enabled squid to develop the most characteristic lifestyle among cephalopods, especially habitation of pelagic waters of the open ocean.

Fecundity is low in squid inhabiting shelf areas where the bottom provides a stable substrate for egg laying. In reef-living Sepioteuthis, only 2 to 6 eggs are laid in a mucous string which is hidden by the female (LaRoe, 1971). The fecundity of shelf-living squid is usually several hundred to several thousand eggs (Loligo sp.). High fecundity is found in squid which 


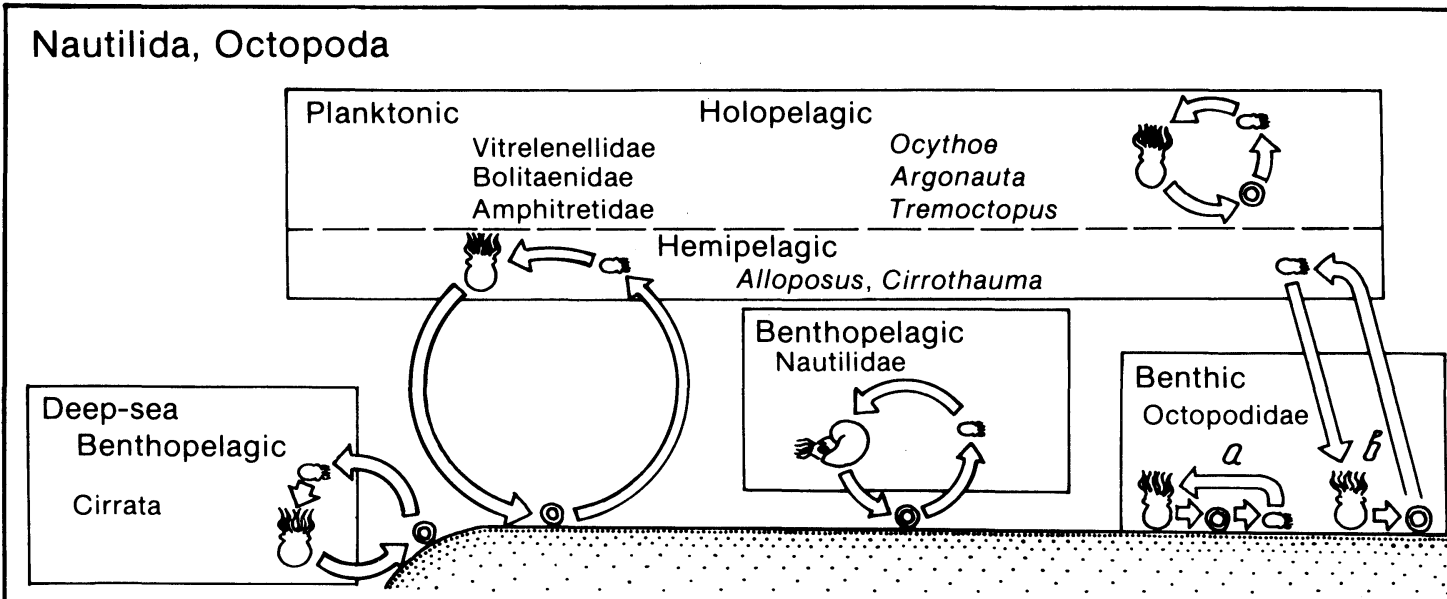

\section{Sepiida}

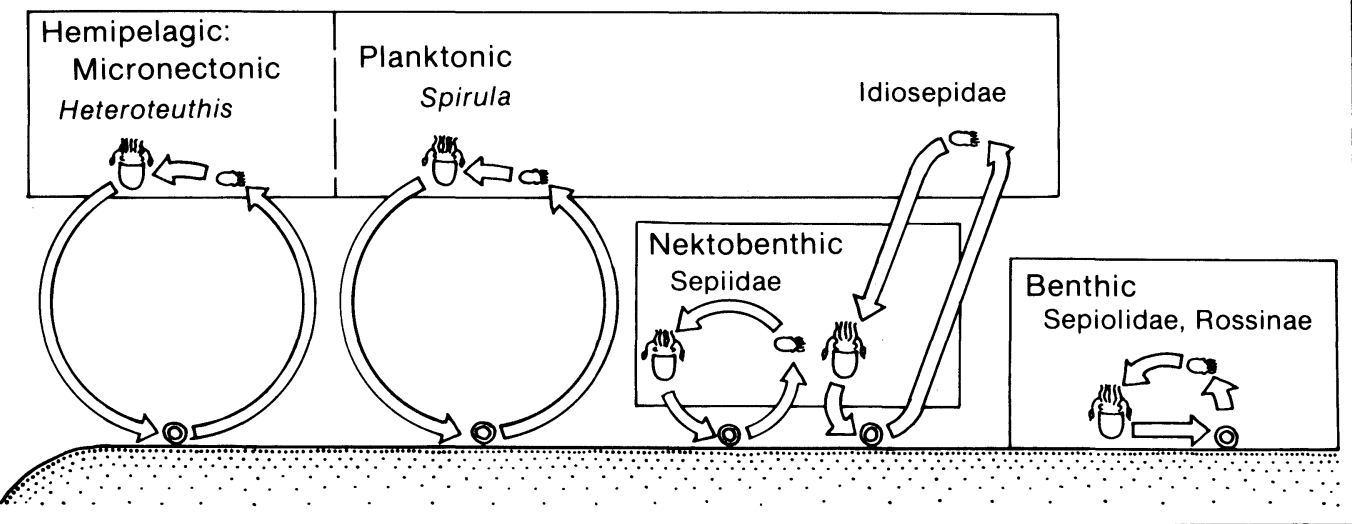

\section{Teuthida}

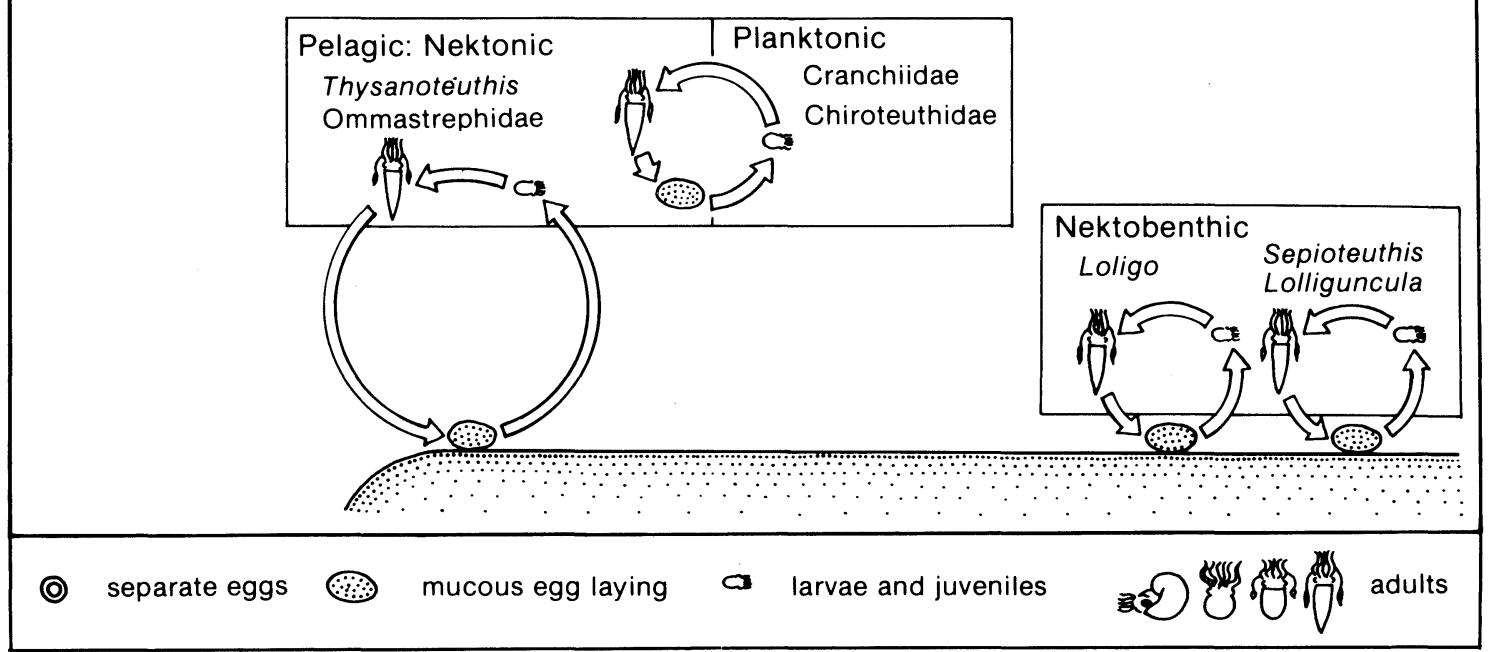

Fig. 2. Basic schemes of life cycles in principal groups of cephalopods (according to Nesis, 1985).

spawn pelagically and in near-bottom waters. This is related to the water column being a more unstable environment where favourable conditions for development are less likely to occur.
Several kinds of $r$-selection (including elements of k-selection) are found in squid. The first and evidently the most primitive is in squid with high fecundity and a prolonged individual maturity period during which the 
female may spawn several times, e.g. Thysanoteuthis, Berryteuthis, Sthenoteuthis (Arkhipkin et al., 1983; Reznik, 1983; Harman et al., 1989). A second kind of $r$-selection occurs in squid with high fecundity as well but they have a short maturity period and once-only spawning (Todarodes, IIlex and others) (Hamabe, 1962; Durward et al., 1980; O'Dor et al., MS 1982). In these, prolonged spawning periods may occur when various subpopulations spawn at different times.

Squid of the subfamily Enoploteuthinae have low fecundity (several hundred eggs) but lay eggs one by one in the water column (Shimamura and Fukataki, 1957; Young and Harman, 1985). Their eggs accumulate in the oviducts and are covered with secretions of oviductal glands only, nidamental glands being absent. Egg protection in this subfamily is achieved by dispersing eggs in the water column which would minimize their selection by small nektonic and planktonic predators. The high abundance of these small short-lived squid indicates that this strategy has enabled them to successfully occupy the micronektonic predator niche.

The kinds of reproductive system structure and function (of females) found in living cephalopods are characteristic of each of the three orders. While different life styles are found in different species of each order, reproductive systems are similar. This may be due to the relative youth (in an evolutionary sense) of the main groups of living cephalopods. Ancient species of different orders with the benthopelagic life style (nautilus and finned octopus) developed similar reproductive systems. In time this could happen with living species of different orders which have similar life styles.

\section{General Scale of Maturity Stages}

A general scale of maturity stages for females and males of the three orders of coleoid cephalopods can be developed from foregoing descriptions of their reproductive systems.

During physiological maturation, similar processes take place in male and female reproductive systems. These include appearance, differentiation and growth of gonad and accessory glands. At this time oogenesis and spermatogenesis take place in the gonads. As already mentioned, gametogenesis differs significantly in different species of cephalopods. Therefore, it is reasonable to distinguish stages of physiological maturation by the degree of gonad and accessory gland development along with the maximum development of mature sexual cells, i.e. physiological maturity.

During functional maturation and maturity, stages are distinguished by the fate of mature sexual cells, particularly by their movement and location in different parts of the reproductive system up to the moment of spawning. The sexual products spawned by males and females differ greatly from each other, e.g. individual eggs of female octopus, mucous egg mass of female squid and spermatophores of male squid. Therefore, it seems inappropriate to include functional maturation and maturity in a single maturity stage (as in Zuev et al., 1985). The processes of formation of sexual products are different in their complexity and significance. However, movement of mature sexual cells to different parts of the reproductive system can be divided into stages which are functionally similar in males and females.

With the foregoing considerations, a general scale for maturity stages is described using only distinctive characteristics necessary for the determination of each stage (Table 1) along with the further commentary and explanation provided below.

Juvenile period - Stage $\mathbf{0}$. Traditionally, numbering of maturity stages began when it was possible to distinguish the sex of an animal visually (Juanico, 1983). In this scale the juvenile phase is referred to as stage " 0 ". It includes two substages:

Pre-differential stage (Stages 0-1). Gonad and accessory gland primordia have appeared but no differentiation has occurred and it is not possible to determine sex. In Sepia this stage covers only a part of embryogenesis, but in Loligo it occurs later in development and starts with the formation of nidamental glands in the post-embryonic period. In the gonads, two types of cells are present, one of which disappears before differentiation is possible.

Post-differential stage (Stages 0-2). Last from the time it is possible to determine sex histologically up to the time it can be distinguished visually. At this stage either gonial cells only, or gonial cells, pre-myotic oocytes and oocytes at phase I protoplasmic growth are present in the female gonad. An exception is the presence of oocytes at the goblet-shaped stage of follicle development in juvenile Loligo opalescens (Knipe and Beeman, 1978).

Physiological maturation and maturity - Stage I. Differentiation and growth of accessory glands make it possible to distinguish sex visually. The gonad is dull grey and filament shaped. The most advanced oocytes are at phase I of protoplasmic growth as in IIlex illecebrosus (Burukovksy et al., MS 1984), Pterygioteuthis gemmata and Tremoctopus violaceus (our data), or at phase II of protoplasmic growth (primary follicle) as in Sthenoteuthis pteropus (Burukovsky et al., 1977) and Gonatus fabricii (our data).

Stage II. Some gonad development and accessory gland growth are evident. The gonad is semitranspar- 
TABLE 1. A general scale of maturity stages for male and female cephalopods. ( $A G=$ accessory glands, oviducal glands, $N G=$ nidamental glands, $S G=s p e r m a t o p h o r i c$ gland, SP = spermatophore, SOC = spermatophoric organ complex.)

\begin{tabular}{|c|c|c|c|c|}
\hline \multicolumn{3}{|c|}{ Female } & \multicolumn{2}{|c|}{ Male } \\
\hline Maturity stage & Octopus and cuttlefish & Squid & Maturity stage & Octopus, cuttlefish and squid \\
\hline Juvenile & $\begin{array}{l}\text { Sex is not distinguishable. } \\
\text { Gonad is a thin filament, } \\
\text { attached to the main blood } \\
\text { vessel of coelom. }\end{array}$ & & Juvenile & The same as in female. \\
\hline $\begin{array}{l}\text { AG appearance and gonad } \\
\text { development. }\end{array}$ & $\begin{array}{l}\text { AG Primordia. OG visible at } \\
\text { both sides of coelom. Gonad } \\
\text { is dull-grey filament. Oocytes } \\
\text { are at phase II (Protoplasmic } \\
\text { growth). }\end{array}$ & & $\begin{array}{l}\text { AG appearance and gonad } \\
\text { development. }\end{array}$ & $\begin{array}{l}\text { Primordium of SOC is visible } \\
\text { on coelom membrane. }\end{array}$ \\
\hline $\begin{array}{l}\text { AG differentiation further } \\
\text { gonad development. }\end{array}$ & $\begin{array}{l}\text { Possible to distinguish parts } \\
\text { of OG and NG. AG are usually } \\
\text { dull white. Gonad has semi- } \\
\text { transparent dull-white } \\
\text { lamina. Oocytes are simple } \\
\text { follicles. }\end{array}$ & & $\begin{array}{l}\text { AG differentiation, further } \\
\text { gonad development }\end{array}$ & $\begin{array}{l}\text { Parts of SOC distinguish- } \\
\text { able. Gonad is dull-white. At } \\
\text { the end of this stage the first } \\
\text { spermatozoa appear in } \\
\text { testis. SG is dull-white }\end{array}$ \\
\hline $\begin{array}{l}\text { Gonad maturation, AG final } \\
\text { formation. }\end{array}$ & $\begin{array}{l}\text { Gonad is large, opaque and } \\
\text { appear granular. Oocytes are } \\
\text { at intercalary and proto- } \\
\text { plasmic growth phase. AG } \\
\text { are completely formed and } \\
\text { usually white. }\end{array}$ & & $\begin{array}{l}\text { Gonad maturation, AG final } \\
\text { formation. }\end{array}$ & $\begin{array}{l}\text { Gonad is large, usually dull- } \\
\text { white. Spermatozoa accu- } \\
\text { mulate in testis ampullae. } \\
\text { SG completely formed, } \\
\text { usually white. }\end{array}$ \\
\hline IV & $\begin{array}{l}\text { IV.-1. First mature eggs } \\
\text { appear in coelom. }\end{array}$ & No accumulation in coelom. & IV & $\begin{array}{l}\text { Spermatozoa extrude into } \\
\text { the coelom. Testis edges } \\
\text { erode. }\end{array}$ \\
\hline $\begin{array}{l}\text { Mature gonad and eggs in } \\
\text { coelom. }\end{array}$ & $\begin{array}{l}\text { IV-2. Mature eggs accumu- } \\
\text { lation in coelom (includes } \\
\text { stage } V \text { ). }\end{array}$ & & $\begin{array}{l}\text { Mature gonad and sperma- } \\
\text { tozoa in coelom. }\end{array}$ & \\
\hline V & Occurs at spawning. & $\begin{array}{l}\text { V-1. First ripe eggs move to } \\
\text { distal end of oviducts. }\end{array}$ & v & $\begin{array}{l}\text { Spermatozoa move into the } \\
\text { spermaduct. No SP in the } \\
\text { Needham sac. }\end{array}$ \\
\hline $\begin{array}{l}\text { Transport of mature eggs in } \\
\text { gonoducts. }\end{array}$ & & $\begin{array}{l}\text { V-2. Eggs accumulate in } \\
\text { oviducts, gonad still func- } \\
\text { tional. } \\
\text { V-3. Eggs accumulate with } \\
\text { gonad eroding. }\end{array}$ & $\begin{array}{l}\text { Transport of mature sperm- } \\
\text { atozoa. }\end{array}$ & \\
\hline VI & Occurs at spawning. & Occurs at spawning. & VI & $\begin{array}{l}\text { VI-1. First SP appears in } \\
\text { Needham sac. }\end{array}$ \\
\hline $\begin{array}{l}\text { Transport of eggs to the } \\
\text { region of } A G \text { secretions. }\end{array}$ & & & $\begin{array}{l}\text { Spermatozoa ready for fer- } \\
\text { tilization. }\end{array}$ & $\begin{array}{l}\text { VI-2. SP accumulate with } \\
\text { testis still functional. } \\
\text { VI-3. SP accumulate with } \\
\text { testis eroding. }\end{array}$ \\
\hline $\begin{array}{l}\text { VII } \\
\text { Gonads spent }\end{array}$ & Gonads spent. & Gonads spent. & $\begin{array}{l}\text { VII } \\
\text { Gonads spent. }\end{array}$ & Gonad spent. \\
\hline
\end{tabular}

ent and laminar form, accessory glands are a dull-white colour and it is possible to distinguish their parts. In Illex illecebrosus active growth of the spermatophoric organs complex (SOC) starts at this stage (Nigmatullin et al., MS 1984). The most advanced oocytes in the ovary are at the primary follicle phase, as in Illex illecebrosus (Burukovsky et al., MS 1984), and Abraliopsis atlantica (our data), and at the start of the simple (goblet shaped) follicle phase, as in Sthenoteuthis pteropus (Burukovsky et al., 1977), Octopoteuthis sicula and Sepiella ornata (our data).

Stage III. The gonad is maturing and accessory glands become fully formed. The gonad is large. In the ovary granular structures are clearly visible. Three substages can be distinguished in females:

III-1. The most advanced oocytes are at the simple follicle phase.
III-2. The most advanced oocytes are at the complex follicle phase.

III-3. The most advanced oocytes are at the trophoplasmic growth phase but none are mature.

The reproductive system in all cephalopod females passes through these three substages. Duration of these stages varies with species. For example in Sthenoteuthis pteropus the main part of stage III falls into substage III-1 (Burukovksy et al., 1977), and in IIlex illecebrosus into substages III-2 and -III-3 (Burukovsky et al., MS 1984). Absence of one or another substage in a species is usually the result of it not lasting very long to be observed and described. In males, formation and accumulation of spermatozoa occur in the testis ampullae so the testis edges do not erode. Accessory glands are opaque, usually white in colour and their parts completely formed and well-developed. 
Stage IV. The gonad is mature. Mature sexual cells are expelled from the gonad into the sexual coelom. In females, ovulation takes place and mature oocytes are transferred into the coelom. This stage is distinguished by the presence of mature oocytes in the ovary and in the coelom. Empty follicles can be seen in the gonad microscopically. At this stage mature oocytes accumulate in the coelom of female Incirrata octopus and cuttlefish. In males, spermatozoa are extruded from the testis ampullae and the edges of the testis show erosion.

Functional maturation and maturity. The remaining stages involve expelling the mature sexual cells from the coelom and their transport through the accumulation in different parts of the sexual viae. Passage of the mature cells through the viae may be subdivided by several conventional boundaries. The first boundary is situated between the entrance of the gonoduct and the coelom, the second between the gonoduct and accessory glands and the third at the exit of the sexual viae (Fig. 1).

In octopus and cuttlefish females, mature oocytes pass through all the conventional boundaries at spawning. In female squid, oocytes pass the first boundary and accumulate in the oviducts prior to spawning. In male squid, the second boundary is open and sperm (as it is converted into spermatophores) moves freely through the spermoatophoric gland to the third boundary (the distal end of the Needham sac) where it accumulates.

Stage $\mathbf{V}$. The mature sexual cells pass into and through the gonaducts. In octopus and cuttlefish females this occurs at spawning. In female squid this stage is usually long and oocytes accumulate in the oviducts. In males this stage is usually short because spermatozoa pass quickly through the spermduct to the spermatophoric gland.

Stage VI. Mature sexual cells pass through the accessory glands. In all cephalopod females this stage occurs at spawning. In males, spermatophores accumulate in the distal part of the Needham sac. However, in the Argonautoidea superfamily only one large spermatophore is formed in the spermatophore gland and passed to the Needham sac. Afterwards its contents appear in the hectocotylus cavity. Spawning takes place with the transfer of the hectocotylus filled with sperm to a female.

Stage VII. Individuals are spent. Degeneration of the reproductive system occurs after spawning. The gonad is greatly reduced in size (compared to stages IV-VI). In a degenerating ovary, oocytes at the trophoplasmic growth phase are practically absent. Some white "islets" can be present on the dull-grey background of a degenerating testis. Accessory glands are usually large and developed as in stages V-VI. How- ever, their consistency has changed from elastic to soft and running. Individuals, as a rule, die at the end of this stage.

General remarks. The foregoing general scale for maturity stages provides a basis for describing most of the different processes of development and functioning of the reproductive systems. Octopus and cuttlefish females are functionally mature at the end of stage IV (stages $\mathrm{V}$ and $\mathrm{VI}$ occur at spawning). Female squid are usually functionally mature in the middle of stage $V$ after portions of the mature oocytes have accumulated in the oviducts. Cephalopod males are functionally mature at stage VI except for the Argonautiodea superfamily where males are functionally mature at stage IV-2.

Some specific examples can be provided to illustrate advantages of this scale. Finned octopus females lay ripe eggs one by one without accumulating them in the coelom. Stage IV indicates the presence of several ripe oocytes in the coelom and stage $V$ when they pass into the oviduct during spanwing. With maturity stages divided into substages, this general scale accounts for specific features of each cephalopod group. For instance, in females of the Ommastrephidae family, substages $\mathrm{V}-1, \mathrm{~V}-2$ and $\mathrm{V}-3$ are readily identified (Burukovsky et al., 1977).

Development and functioning of the reproductive system in male and female cephalopods are generally similar (Table 1). However, the duration and especially the ecological significance of each stage are quite different. Since each stage of sexual maturation usually corresponds to a particular feature of the animals ecology (Froerman, MS 1985), infrequent occurrence of any stage means either that animals cannot be found at this stage or that the stage is of short duration. For instance, stage IV (physiological maturation) is important for octopus and cuttlefish females because at this stage ripe oocytes accumulate in the coelom. This stage is short and of less signficance in female squid because they accumulate ripe oocytes in the coelom at stage $V$. In male cephalopods, stages IV and V are short and perhaps of little ecological importance since they have to accumulate a large quantity of spermatophores in the Needham sac at stage VI. The duration of each stage is an indication of its ecological significance for the species and provides a more thorough understanding of its life cycle. Another advantage of this general scale for maturity stages is that it also allows an evolutionary consideration of the development of reproductive strategies within various cephalopod groups.

\section{Acknowledgements}

The creative atmosphere at the AtlantNIRO commercial invertebrates laboratory, along with discussions on problems of cephalopod reproductive biology 
with my scientific supervisors Ch. M. Nigmatullin and R. N. Burukovsky, contributed substantially to this paper. I also gratefully acknowledge B. G. Ivanov, K. N. Nesis, Ya. I. Starobogatov, Yu. A. Filippova, Yu. M. Froerman and F. E. Alexeev for their valuable comments and A. S. Schetinnikov, R. M. Sabirov and especially V. V. Laptikhovsky for their assistance and participation in the discussion of results.

\section{References}

ALDRED, R. G., M. NIXON, and J. Z. YOUNG. 1983. Cirrotauma murrayi Chun, a finned octopod. Phil. Trans. Roy. Soc. Lond. (Biol. Sci.), 301: 1-54.

ARKHIPKIN, A. I., Ch. M. NIGMATULLIN, R. M. SABIROV, and K. D. SHILIN. 1983. Morphology and characteristic features of sexual system functioning in Thysanoteuthis rhombus squid. In: Systematics and ecology of cephalopod molluscs, Leningrad, Nauka press, p. 59-61.

ARNOLD, J. M., and L. D. WILLIAMS-ARNOLD. 1977. Cephalopoda: decapoda. In: Reproduction of marine invertebrates, Molluscs: Gastropods and Cephalopods, Vol. 4. A. G. Giese and J. S. Pears (eds.). Academic press, p. 243290.

BOLETZKY, S. von. 1978. Premieres donnees sur le developpement embryonnaire du sepiolide pelagique Heteroteuthis (Mollusca, Cephalopoda). Haliotis, 9: 81-84.

1979. Nos connaissances actuelles sur le developpement des octopodes. Vie Milieu, 28, (AB): 85-120.

1981. Reflexions sur les strategies de reproduction chez les Cephalopodes. Bull. Soc. Zool. France, 106(3): 293-304.

1983. Sepia officinalis. In: Cephalopod life cycles, (vol. 1, p. 31-52). P. R. Boyle (ed)., Academic press.

1986. Reproductive strategies in cephalopods: variation and flexibility of life-history patterns. Adv. Inv. Reprod., vol. 4, p. 379-389, Elsevier Publishers.

BOTTKE, W. 1974. The fine structures of the ovarian follicle of Alloteuthis subulata Lam. Cell. Tissue Res., 150(4): 463479.

BUCKLEY, S. K. L. 1976. Octopus gonadotropin and its role in the regulation of egg development. Colloq. Int. CNRS, v. 251, 161-167.

BURUKOVSKY, R. N., YU. M. FROERMAN, and Ch. M. NIGMATULLIN. MS 1984. Reproductive biology and scale of maturity stages of reproductive system of female squid (IIlex illecebrosus). NAFO SCR Doc., No. 120, Serial No. N917, $4 \mathrm{p}$.

BURUKOVSKY, R. N., G. V. ZUEV, Ch. M. NIGMATULLIN, and M. A. TSYMBAL. 1977. Methodological background for creating maturity scales of squid female reproductive system on the example of Sthenoteuthis pteropus (Cephalopoda, Ommastrephidae). Zool. Zh., 12: 17811791.

$\mathrm{CHOE}, \mathrm{S}$. 1966. On the eggs, rearing, habits of the fry and growth of some Cephalopoda. Bull. Mar. Sci., 16: 330-348.

CHUKCHIN, V. D. 1984. Ecology of gastropod molluscs from the Black Sea. Kiev, Naukova Dumka press, $176 \mathrm{p}$.

COWDEN, R. R. 1968. Cytological and cytochemical studies of oocyte development of the follicular epithelium in the squid Loligo brevis. Acta Embryol. Morphol. Exp., 10: 160-173.
DREW, G. A. 1919. Sexual activities of the squid Loligo pealei (Les.) 2. The spermatophore, its structure, ejaculation and formation. J. Morphol., 32: 379-435.

DURWARD, R. D., E. VESSEY, R. K. O'DOR, and T. AMARATUNGA. 1980. Reproduction in squid, Illex illecebrosus: first observation in captivity and implications for the life cycle. ICNAF Sel. Papers, 6: 7-13.

FIELDS, W. G. 1965. The structure, development, food relations, reproduction and life history of the squid Loligo opalescens Berry. Fish. Bull. Calif. Dep. Fish Game, 131: 1-108.

FIORONI, P. 1978. Cephalopoda, Tintenfische. In: Morphologie der Tiere. VEB Gustav Fischer Verlag, Jena, $181 \mathrm{p}$.

FROERMAN, Yu. M. MS 1985. Ecology and mechanism of abundance dynamics of the short-finned squid IIlex illecebrosus. Ph.D. Thesis Abstract, Moscow, Shirshov Institute of Oceanography, $24 \mathrm{p}$.

GRIEB, T. M., and R. D. BEEMAN. 1978. A study of spermatogenesis in the spawning population of the squid Loligo opalescens. Fish. Bull. Calif. Dept. Fish. Game, 169: 11-20.

HAMABE, M. 1962. Embryological studies on the common squid, Ommastrephes sloani pacificus Steenstrup, in the southwestern waters of the Sea of Japan. Bull. Jap. Sea Reg. Fish. Res. Lab., 10: 1-45.

HARMAN, R. F., R. E. YOUNG, S. B. REID, K. M. MANGOLD, T. SUZUKI, and R. E. HIXON. 1989. Evidence for multiple spawning in the tropical oceanic squid Sthenoteuthis oualaniensis. Mar. Biol., 101(4): 513-519.

JUANICO, M. 1983. Squid maturity scales for population analysis. In: Advances in assessment of world cephalopod resources (p. 341-378), J. F. Caddy (ed.), FAO Fish. Tech. Pap., 231: 452 p.

KNIPE, J. H., and R. D. BEEMAN. 1978. Historical observation on oogenesis in Loligo opalescens. Fish. Bull. U.S., 169: 23-33.

LAPTIKHOVSKY, V. V., and Ch. M. NIGMATULLIN. 1987. Phenomenon of previous spermatophores in cephalopod molluscs. In: Molluscs. Results and prospects of their investigations. Leningrad, Nauka press, p. 240-242.

LaROE, E. T. 1971. The culture and maintenance of the loliginid squids Sepioteuthis sepioidea and Doryteuthis plei. Mar. Biol., 9: 9-25.

LeMAIRE, J. 1972. Survie et differentiation d'organes embryonnaires de Sepia officinalis L. (Mollusca, Cephalopoda) en culture in vitro. C. R. Hebd. Sceances. Acad. Sci., Ser. D., vol. 275, p. 259-262.

MICHEL, E. G., A. T. KLETT, and R. I. OCHOA. 1986. Estudio preliminar para la determinacion de madurez gonadica del calamar gigante Dosidicus gigas (d'Orbigny, 1835). Cienc. pesq., 5: 77-89.

NESIS, K. N. 1982. Concise key for determination of cephalopod molluscs of the World Ocean. M., Liogkaya i pisch. promyslennost, $360 \mathrm{p}$.

1985. Oceanic cephalopod molluscs. Distribution, living forms and evolution. Moscow, Nauka press, $288 \mathrm{p}$.

NIGMATULLIN, Ch. M., R. M. SABIROV, and Yu. M. FROERMAN. MS 1984. Reproductive biology and scale of maturity stages of the reproductive system of male squid (IIlex illecebrosus). NAFO SCR Doc., No. 119, Serial No. N916, $3 \mathrm{p}$.

O'DOR, R. K., and N. BALCH. 1985. Properties of /llex illecebrosus egg masses potentially influencing larval oceanographic distribution. NAFO Sci. Coun. Studies, 9: 69-76. 
O'DOR, R. K., N. BALCH, and T. AMARATUNGA. MS 1982. Laboratory observation of midwater spawning by Illex illecebrosus. NAFO SCR Doc., No. 5, Serial No. N493, 6 p.

PUJALS, M. A. 1986. Contribucion al conocimiento de la biologia de Octopus tenuelchus d'Orbigny (Mollusca: Cephalopoda). An. Soc. Cient. Argent., 214: 29-71.

REZNIK, Ya. I. 1983. General morphology of reproductive system in Berryteuthis magister. In: Systematics and Ecology of Cephalopod Mollusks. Leningrad, Nauka press, p. 64-66.

RODANICHE, A. F. 1984. Iteroparity in the lesser Pacific striped octopus Octopus chierchiae (Jatta, 1889). Bull. Mar. Sci., 35(1): 99-104.

SABIROV, R. M., A. I. ARKHIPKIN, V. YU. TSYGANKOV, and A. S. SCHETINNIKOV. 1987. Egg-laying and embryonic development of the diamond-shaped squid Thysanoteuthis rhombus (Oegopsida, Thysanoteuthidae). Zool. Zh., 66(8): 1155-1163.

SANZO, L. 1929. Nidamento pelagico, uova e larvi di Thysanoteuthis rhombus Troschel. Mem. R. Comm. talassogr. ital., 161: 1-10.

SHIMAMURA, S., and H. FUKATAKI. 1957. Squids. In: On the year occurrence and ecology of eggs and larvae of the principal fishes in the Japan Sea. Bull. Jap. Sea Reg. Fish. Res. Lab., 6: 269-283.

SHULDT, M. 1979. Contribucion al conocimiento del ciclo reproductor de Illex argentinus (Cephalopoda, Ommastrephidae). Monogr. Comm. Invest. Cient. Argent., 10: $110 \mathrm{p}$.

TAKI, I. 1945. Studies on Octopus. 2. Sex and genital organs. Jap. J. Malacol., 13(5-8): 267-310.

THE MOLLUSCA. 1988. Paleontology and neonatology of cephalopods. Carl M. Wilbur and M. R. Clark (eds.), Academic Press, London, p. ?? - ??.

WELLS, M. J., and J. WELLS. 1977. Cephalopoda: Octopoda. In: Reproduction of marine invertebrates, Molluscs: Gastropods and Cephalopods, vol. 4. A. Giese and J. S. Pearse (eds.), Academic press, p. 291-337.

YOUNG, R. E., and R. F. HARMAN. 1985. Early life history stages of enoploteuthin squids from Hawaiian waters. Vie Milieu, 35(3-4): 181-202.

ZUEV, G. V., Ch. M. NIGMATULLIN, and V. N. NIKOLSKY. 1985. Nektonic oceanic squids. Moscow, Agropromizdat, $224 \mathrm{p}$. 